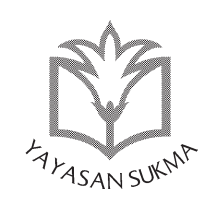

SUKMA: JURNAL PENDIDIKAN

ISSN: 2548-5105 (p), 2597-9590 (e)

Volume 3 Issue 1, Jan-Jun 2019, pp. 1-18

https://doi.org/10.32533/03101.2019

www.jurnalsukma.org

\title{
ADULT ATTACHMENT FOR RECONSTRUCTING ADOLESCENTS' LEARNING IDENTITY AND AWARENESS
}

\section{Ratna Sari Dewi; Nurhayati}

Sukma Bangsa Pidie School, Aceh, Indonesia; School of Education, University of Tampere, Tampere, Finland email: nurhayatim87@gmail.com

\section{Abstract}

This study explored how adolescents reconstructed their roles as learners through learning identity and awareness by adult involvement in Sukma Bangsa Pidie (SBP) School. It is argued that the child would grow as a good learner with positive improvement of self-concept and self-esteem. Also, the formation of positive self-esteem in adolescence became a bridge towards their success as demanding learners. Furthermore, adult (in this case teachers and parents) involvement with adolescents' learning approaches may embolden the learners to 
become less or more autonomous people. Positive adult attachment therefore is pivotal to moderate students who have either low willingness to study or low selfconception. This study ultimately confirmed that there was a reciprocal relationship between learner identity (motivation, self-perceptions, autonomy, self-development) and learner awareness (survival, establishing stability, approval, loving to learn), then further will support the integrated effects on learner autonomy.

Keywords: adult attachment, identity, awareness, adolescent learner

\section{A. Introduction}

Identity formation can be explored from either personal actions or conversation, which occurs together with human interactions. When individual attempts to create interactions to others, then it can be understood as narratives. In this case, positioning theory explains personal narratives appropriately, it means the researchers have to be able to construct social reality into discursive discussion whereby a phenomenon from conversation can be claimed as positioning. Tirado and Galvez (2008) clearly stated that discourse represents a whole of social and dynamic interactions and multiple meaning, which can be constructed and transformed, rather than individual or personal action. Therefore, it is important to understand that positioning sense has potentially changed periodically.

Positioning theory (van Langenhove and Harré 1999) is "the study of the nature, formation, influence, and ways of change of local systems of rights and duties as shared assumptions about them influence small-scale interactions." Positioning theory is to be seen in contrast to the older framework of role theory, and the advent of positioning theory is a development of Vygotsky's conception (Harré 2004). In this study, positioning theory is related to the way adolescents positioned themselves as learners 
(determined position), so that they will perceive and understand learning activities from and through the position that they have. As cited in Tirado and Galvez (2008), positioning is "a term that refers to the actions in which competent people find themselves in and are bound by their interaction within a system of rights and responsibilities, of possibilities and nonsense".

Adolescents who already know their position as students, they tend to be responsible for their own learning. Position in the social context means distribution; there are "I" and "other". As recorded from Harré, et al. (2009) publication, positioning theory "concerned with revealing the explicit and implicit patterns of reasoning that are realized in the ways that people act towards others." As an illustration, a teacher has the right to assist and guide their students in some particular approaches regarding students' needs, but other people cannot (Harré 2004).

In adolescents' identity positioning, attachment from other people who close to them is important as well, in this case students may feel secure when those people are available to them whenever they need. For that purpose, attachment theory is needed in order to provide some adolescents in their development tasks regarding relationship for social as well as emotional development (Bowlby and Ainsworth 1969).

When learners have a tendency to look for at least one caregiver, or motivator, or even facilitator that they trust whether she or he may be able to help them, then this attachment leads security, love, joy, and also can facilitate and motivate them to study for some particular cases. In contrast, without an attachment, let say an adult, adolescents tend to have anxiety and even depression. For instance, a healthy relationship of teachers and students encourages students to enhance their study progress, and later leading students to build their identity characteristics as learners.

Furthermore, attachment theory also stressed on the adolescents' experience to reassure what they need both present and, in the future, by supporting from an adult (or in this case a 
teacher), they will feel more confident about their choices and decisions. In addition, according to Bowlby and Ainsworth (1969), all human requires several aspects that will influence their emotional needs; they are attention, acceptance, appreciation, encouragement, affection, respect, support, comfort, approval, and security. Therefore, to achieve the formation of learners' identity, what teachers need is to provide those aspects along with the attachment to their students.

Attachment theory is "a psychological, evolutionary, and ethological theory concerning relationships between humans". Four-quadrant model of adult attachment are adopted in this study, and according to Bartholomew (1990) and Bartholomew and Horowitz (1991), they are secure, preoccupied, dismissing, and fearful. Figure 1 depicts model of adult attachment as cited in Riley (2011). These four models of attachment as cited in Riley (2011, 33-38) and Lewis (2006) can be described as follows:

The secure teacher's interest is mainly focused on understanding her students. The preoccupied teacher may appear to be inconsistent in her treatment of students, over valuing some and devaluing others. The dismissing teacher may be the type of teacher who tends to "stay on the case" of certain students, always catching them behaving badly and always failing to catch them doing well or being socially proactive. The fearful teacher experiences an increased sense of unworthiness when compared

\begin{tabular}{|c|c|c|c|}
\hline & \multicolumn{2}{|c|}{ Model of Self (Dependence) } \\
\hline & & Positive (Low) & Negative (High) \\
\hline \multirow{2}{*}{ 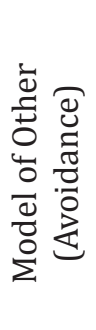 } & 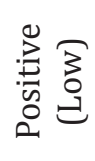 & $\begin{array}{c}\text { Secure } \\
\text { Comfortable with } \\
\text { intimacy and autonomy }\end{array}$ & $\begin{array}{c}\text { Preoccupied } \\
\text { Preoccupied with rela- } \\
\text { tionships }\end{array}$ \\
\hline & 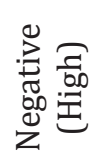 & $\begin{array}{c}\text { Dismissing } \\
\text { Dismissing of intimacy } \\
\text { Counter-dependent }\end{array}$ & $\begin{array}{l}\text { Fearful } \\
\text { Fearful of intimacy } \\
\text { Socially avoidant }\end{array}$ \\
\hline
\end{tabular}

Figure 1: Model of adult attachment (Riley 2011) 
to the other attachment styles.

Hence, to be a secure teacher is very pivotal in order to provide students appropriate treatments, and later may encourage the teacher to increase students' learning awareness by creating good relationship between teacher and students properly. Accordingly, a secure teacher together with parents have potency to help students to understand their positions as learners. Students ultimately are motivated to achieve their goals as they want to be.

\section{B. Descriptive Categories}

The descriptions of categories are presented to respond all research questions that were previously given. We emphasize on both learner identity and awareness that affect adolescents' identity formation as also consulted from previous studies (APA 2002; Byrne 1984; Bong and Skaalvik 2003; Schunk 1991; Adamson, Hartman and Lyxell 1999; Andrade and Du 2007; Spiller 2012; Bandura and Adams 1977; Matthews, Banerjee and Lauermann 2014; Harrison 1978; Song and Hill 2007; Hiemstra 1994; Choy et al. 2015; Choy et al. 2016). Our first assumption is learner identity will be constructed from adolescents' motivation and self-perceptions and later may encourage their awareness as learners at a certain point. In positioning themselves as learners, adolescents experience such different ways over the time, which are influenced by their surroundings instead of individuals themselves.

Learner identity can be clearly defined as "the individual's sense of recognition as a learner based on the constantly reconstructed meanings about herself as a learner with a higher or lower level of disposition and capacity to learn in different kinds of contexts and situations" (Falsafi 2010,94). Meanwhile, learner awareness is concretely understood as how "students describe them as being related to their motive to learn and the strategies used, hence their overall experience" (Choy et al. 2016, 94). The findings of this study relating to the different ways' adolescents 
Ratna Sari Dewi; Nurhayati

construct their learner identity and awareness further is discussed in the next subheadings. Figure 2 shows the descriptions

Categories Descriptions

A. Learner identity (Bandura, 1977; Baumeister, 1999; Fredricks, et al., 2004; Maehr and Meyer, 2004; Reeve, 2006; Holec, 1979)

\begin{tabular}{|c|c|}
\hline Self-efficacy & $\begin{array}{l}\text { Learners are able to perceive their effort, intended to face } \\
\text { obstacles, anxiety, and defensive behavior. }\end{array}$ \\
\hline Self-concept & $\begin{array}{l}\text { Learners can build or at least to recognize their own belief } \\
\text { about themselves including personal attributes, who, and } \\
\text { what the self is (learners' ideas about themselves). }\end{array}$ \\
\hline Self-esteem & $\begin{array}{l}\text { Learners understand the way they evaluate themselves, } \\
\text { and at this point learners are expected to present broadest } \\
\text { self-evaluation. }\end{array}$ \\
\hline $\begin{array}{l}\text { Self-develop- } \\
\text { ment }\end{array}$ & $\begin{array}{l}\text { Learners are able to develop and be responsible for both } \\
\text { their own and other people learning (agency) with taking } \\
\text { account on assessment process as well as reflection. }\end{array}$ \\
\hline Motivation & $\begin{array}{l}\text { Learners indicate a state that energizes, directs, and sus- } \\
\text { tains behavior. }\end{array}$ \\
\hline Autonomy & $\begin{array}{l}\text { Learners are independent in deciding their own learning } \\
\text { instead of to be dependent on the teachers or parents. }\end{array}$ \\
\hline \multicolumn{2}{|r|}{ B. Learner awareness (Choy et al., 2016, p. 97) } \\
\hline Survival & $\begin{array}{l}\text { This level represents learner's fear of authority and fulfill- } \\
\text { ing a need that they have toward learning. }\end{array}$ \\
\hline $\begin{array}{l}\text { Establishing } \\
\text { stability }\end{array}$ & $\begin{array}{l}\text { This level is about striving to achieve and having no } \\
\text { choice, which is reflective of actions that they can take at } \\
\text { this level. }\end{array}$ \\
\hline Approval & $\begin{array}{l}\text { This level refers to reflective of the actions they would } \\
\text { carry out to meet the approval of others. }\end{array}$ \\
\hline $\begin{array}{l}\text { Loving to } \\
\text { learn }\end{array}$ & $\begin{array}{l}\text { This level is used to describe an individual's motivation to } \\
\text { acquire new skills and build on existing knowledge. }\end{array}$ \\
\hline
\end{tabular}

Figure 2: Key concepts used in this research 
of key concepts used in this study.

Recently, the concept of identity for students, particularly adolescents, becomes more popular in the educational research regarding the urgency for educational stakeholders (i.e. teachers, schools, parents) to deal with the phenomenon that frequently occurs. In their period, adolescents are extremely overcoming complicated problems due to their identity confusion. We credited that either to position or to be positioned themselves (adolescents) as learners plays a pivotal factor in shaping learner identity and affects their willingness to study, emotional experiences, academic attitude whether to be success or failure, anxiety, and later their awareness to be involved in learning environment.

Therefore, in this study, several main experiences observed from student participants are proposed in the following aspects:

a) Adolescents' willingness to study

b) Adolescents' emotional experiences

c) Adolescents' confidence

d) Adolescents' cognitive ability

e) Adult (parents and teachers) attachment

These five aspects then will be indicators for the researchers to assess each item of both learner identity and awareness in terms of the different ways' adolescents experienced their positions as learners in the school.

\section{Adolescents' Identity Positioning as Learners}

In the previous discussion (Ratna S. D., et. al. 2017), during her presentation at International Conference (Hong Kong), entitled "What leads adolescents confused with their learning identity in Sukma Bangsa Pidie (SBP) School", the students in this study exhibited a high level of self-efficacy and self-development, an average level of self-esteem and autonomy, and close to an average level of self-concept and motivation in constructing their identity as learners. Moreover, in relation to adult attachment, adult (in this case teachers and parents) involvement with 
adolescents' learning approaches may embolden the learners to become less or more autonomous people. Positive adult attachment therefore is pivotal to moderate students who have either low willingness to study or low self-conception.

Additionally, the authors in the previous study (Nurhayati, et. al. 2017) also found that students in SBP School were in various categories regarding their levels of learning awareness. Concerning on how learners' identity was reconstructed through learning awareness, the research exhibited by how students dealt with their own learning approaches and how high their existing willingness to learn was. The different levels of learning awareness were survival, establishing stability, approval, and loving to learn. The findings also demonstrated that most students in this school were at the level of establishing stability, although some students were still at the survival level, and in between establishing stability and survival (Figure 3). In addition, as illustrated in Figure 4, both learner identity and learner awareness level were almost similar in the way that adolescents experienced. As argued by previous well-known researchers, the child would grow as a good learner with positive improvement of self-concept and selfesteem. Also, the formation of positive self-esteem in adolescence

\begin{tabular}{lcccccc}
\hline Experience & $\begin{array}{c}\text { Self- } \\
\text { efficacy }\end{array}$ & $\begin{array}{c}\text { Self- } \\
\text { concept }\end{array}$ & $\begin{array}{c}\text { Self- } \\
\text { esteem }\end{array}$ & $\begin{array}{c}\text { Self- } \\
\text { develop- } \\
\text { ment }\end{array}$ & $\begin{array}{c}\text { Motiva- } \\
\text { tion }\end{array}$ & $\begin{array}{c}\text { Autono- } \\
\text { my }\end{array}$ \\
\hline $\begin{array}{l}\text { Willingness } \\
\text { to study }\end{array}$ & High & Fair & Fair & Fair & Fair & High \\
\hline Emotional & Fair & Fair & Fair & High & Fair & Fair \\
\hline $\begin{array}{l}\text { Showing } \\
\text { confidence }\end{array}$ & High & High & High & High & Fair & High \\
\hline $\begin{array}{l}\text { Cognitive } \\
\text { ability }\end{array}$ & High & Low & Fair & High & High & Fair \\
\hline $\begin{array}{l}\text { Adult at- } \\
\text { tachment }\end{array}$ & Low & Fair & Fair & Low & Low & Low \\
\hline
\end{tabular}

Figure 3: Adolescents' experiences in constructing identities as learners (Ratna S. D. et al. 2017; Nurhayati et al. 2017) 
became a bridge towards their success as demanding learners. This study ultimately confirmed that there was a reciprocal relationship between learner identity (motivation, self-perceptions, autonomy, self-development) and learner awareness (survival, establishing stability, approval, loving to learn), then further will support the integrated effects on learner autonomy.

To respond the question "what are qualitatively the different ways of experiencing adolescents' position as learners in the school," this study will further discuss the final outcome space of adolescents' identity positioning as learners in order to follow up the authors' assumption. The summary of adolescents' experiences (with sample of interview transcripts) in their positions as learners is displayed in Figure 4. Overall, most students were able to position themselves as learners regarding their responses given as can be clearly seen on the students' experiences from interview transcripts, particularly in the ways they perceived their self-efficacy, self-concept, and self-esteem.

The use of "I" emphasizes their strong position as individuals, in this case as learners. Adolescents who already know their position as students or learners, they tend to be responsible for their own learning. According to van Langenhove and Harré $(1999,25)$, "when a person is engaged in a deliberate selfpositioning process this often will imply that they try to achieve specific goals with their act of self-positioning". It further associates with self-directed learning because autonomy as learners that they have. To support the actions of what people do, selfpositioning plays an important role in the cognitive processes, which assist the explanations of actions that people are attending (Harré et al. 2009).

From the student's excerpt of self-efficacy, we detect that the degree of student's accomplishment ranging from fair to high, the example demonstrated whether the student was very sure about his responsibility as a learner, as he mentioned that "every weekend I normally do independent learning". This is part of his willingness to study by using his learner autonomy appropriate- 


Cate-
gories $\begin{gathered}\text { Degree of } \\ \text { accom- } \\ \text { plishment }\end{gathered} \quad$ Interview Transcripts

\section{A. Learner identity}

\begin{tabular}{|c|c|c|}
\hline $\begin{array}{l}\text { Self- } \\
\text { efficacy }\end{array}$ & Fair to high & $\begin{array}{l}\text { "Every weekend I normally do independent learning, such as look- } \\
\text { ing for additional knowledge from internet (...)" }\end{array}$ \\
\hline $\begin{array}{l}\text { Self- } \\
\text { concept }\end{array}$ & Fair & $\begin{array}{l}\text { "How to say... I'm a fussy person... eum, I love to make a joke, but } \\
\text { when I'm serious, I don't like to be bothered by others." }\end{array}$ \\
\hline $\begin{array}{l}\text { Self- } \\
\text { esteem }\end{array}$ & Fair to high & $\begin{array}{l}\text { "Ooo... I have average scores, and high scores as well... most of my } \\
\text { scores are high." }\end{array}$ \\
\hline $\begin{array}{c}\text { Self- } \\
\text { devel- } \\
\text { opment }\end{array}$ & Fair to high & $\begin{array}{l}\text { "I like, for example, the teacher gives the assignments, for those } \\
\text { who can answer then will get additional marks, and the problems } \\
\text { are harder... it becomes challenges for all of us, I love it." }\end{array}$ \\
\hline $\begin{array}{l}\text { Motiva- } \\
\text { tion }\end{array}$ & Fair & "Yes, study seriously, I love my parents." \\
\hline $\begin{array}{l}\text { Autono- } \\
\text { my }\end{array}$ & Fair to high & $\begin{array}{l}\text { "Complain about score? (...) aaa... mathematics, often, often I com- } \\
\text { plain about the score }(\ldots) \text { because what I think it was correct }(. . .) \\
\text { was mistaken [by my teacher]." }\end{array}$ \\
\hline
\end{tabular}

\section{B. Learner awareness}

\begin{tabular}{|c|c|c|}
\hline Survival & Low to fair & $\begin{array}{l}\text { "(...) I feel happy in this school, the teacher really cares about us (...) } \\
\text { here, I could be easily close to the other friends, because they are } \\
\text { kind people (...) I will study hard, I want to make my parents happy } \\
(\ldots . .)\end{array}$ \\
\hline $\begin{array}{l}\text { Estab- } \\
\text { lishing } \\
\text { stabil- } \\
\text { ity }\end{array}$ & Low to fair & $\begin{array}{l}\text { “(...) That is why I like mathematics and I learn to like drawings, } \\
\text { because we need it in architecture design, we will design houses or } \\
\text { build (...) I like mathematics because I have purpose to continue my } \\
\text { study in civil engineering (...)" }\end{array}$ \\
\hline $\begin{array}{c}\text { Ap- } \\
\text { proval }\end{array}$ & Fair to high & $\begin{array}{l}\text { “(...) I am happy to be a part of this school, we have nice teach- } \\
\text { ers here (...) I got scholarship and must stay in dormitory, I am } \\
\text { happy to stay in dormitory (...) yes, I tell the truth (...) I have a lot of } \\
\text { friends here (...) I'm responsible for worship department and teach } \\
\text { Iqra' [manual for Quranic reading lesson] for my youngest friends } \\
\text { in dormitory (...) yes, I am a leader in my classroom (...) I asked my } \\
\text { friends to do the task, I told something in a good way and they fol- } \\
\text { low my instructions (...)” }\end{array}$ \\
\hline $\begin{array}{l}\text { Loving } \\
\text { to learn }\end{array}$ & High & $\begin{array}{l}\text { “(..) my favorite subjects are mathematics and biology (...) because } \\
\text { it is challenging, for mathematics, if we have already finished and } \\
\text { solved the problems, it looks like we are very smart, then, biology } \\
\text { (...) biology, I like it since I was young, I don't care, whether I can } \\
\text { understand or not, still I like biology (...)" }\end{array}$ \\
\hline
\end{tabular}

Figure 4: Summary of adolescents' experiences in their posi-
tions as learners (Nurhayati, et. al. 2017) 
ly. In addition, another example in terms of student's motivation exhibited a fair level of her achievement as clearly stated that she studied seriously because she loved her parents. It showed her willingness to fulfil parents' expectation on her achievements and later we understand this as her external motivation.

Furthermore, regarding learner awareness, the level positioned her on survival, because she studied due to her environment influences. What is more, the insecure adult attachment, in her case was parents, encouraged her to consider other people rather than her own side. As discussed in Riley (2011) based on adult attachment model proposed by Bartholomew (1990) and Bartholomew and Horowitz (1991), this type of parents employs preoccupied relationship with their children, and it may lead their children become less autonomous people.

Alternatively, for student's self-development example, we figure out that the student who had fair to high degree accomplishment already had higher autonomy as a learner, as he mentioned whether he would be happy to be challenged by assignments given and also he loved it. What we can understand here is this type of teacher applied a secure attachment, as stressed by Riley $(2011,34)$ that the secure teacher "uses the experience to shape and improve her own practice, she seeks to have her internal working model confirmed and does so in ways that benefit the students, the teacher and the relationship between them". In the relation to learner awareness, the level of the student mentioned above was at loving to learn due to his full autonomy of learning process and approach.

More importantly, according to Vagan (2011), positioning has already been a good metaphor for adolescents to explore about themselves in the social context and later they are able to clarify their action meanings. As we can perceive from one of student's experiences from Figure 4:

“(...) I am happy to be a part of this school, we have nice teachers here (...) I got scholarship and must stay in dormitory, I am happy to stay in dormitory (...) yes, I tell the truth (...) 
I have a lot of friends here (...) I'm responsible for worship department and teach Iqra' [manual for Quranic reading lesson] for my youngest friends in dormitory (...) yes, I am a leader in my classroom (...) I asked my friends to do the task, I told something in a good way and they follow my instructions (...)"(S1 Interview, 06 October 2016)

He clearly positioned himself as both a good learner and a competent teacher for his friends, and he did it happily. He further demonstrated his responsibility as a leader for his class as well, and it showed a high level of confidence that he had. We counsel that such a particular activity reinforced the student to construct the meanings about himself regarding his identity. This became part of his recognition as a learner, a teacher, and a leader.

In line with this issue, Coll and Falsafi (submitted) and Falsafi and Coll (in press) as cited in Falsafi (2010) stated that recognition notion is fundamental for the concept of identity formation. Importantly, to understand the meaning of a phenomenon in the social context may encourage the student to be able to adopt the similar thought about his or herself in the new learning situations (Falsafi 2010). Another study from Yamakawa et al. (2005) confirmed that role of positioning has strong effect on students' identities as competent learners.

However, we conceive that both teachers (at school) and parents (at home) must absolutely assist students with low levels of motivation and self-perception. Figure 2 displays the outcome space of adolescents' identity positioning as learners, which are purported by the researchers as the overall findings of this study. Basically, in constructing their identity as learners, adolescents must able to have a sense of learner identity, as indicated by their willingness to study, emotional experiences, and level of confidence. Learner identity in this study refers to several main aspects, specifically motivation, self-perceptions (includes self-efficacy, self-concept, and self-esteem), autonomy, and selfdevelopment.

Above all, learner identity is essential to shape and con- 
struct the awareness level of learners. Hence, we then attempt to understand the association of learner identity formation with the awareness level of learners in this context. Regarding the different way adolescents perceive their positions as learners, we find a gap between one student's experiences and the other students' experiences, which is attachment from adult (teachers and parents). Bosnjak and Winkelman (2003) confirmed the similar phenomena, because they stressed that self-perception (i.e. self-esteem) and healthy attachment has a complex relation to identity formation. Attachment from adults plays a pivotal role in reconstructing learner identity by intervening in adolescents' awareness development (Hirano 2011). We therefore suggest adult attachment as a means to moderate students with low levels of either motivation or self-perceptions in order to reconstruct students' learning identities properly.

Moreover, another experience that we highlight is the cognitive ability of students. As previously explained, students' cognitive capability stands as an independent aspect compared to the other four experiences, hence, not all students with a high level of learner awareness have excellent cognitive achievements, but also the lower level ones may have it, and vice versa.

\section{Concluding Remarks}

This research employed a phenomenographic approach in the interpretation of the results, hence, readers then may have their own conclusions to justify the outcome spaces of the study. We understand that there are various backgrounds of readers, influencing the way they interpret and determine the meanings of these findings, regarding their different points of view. Therefore, the conclusions provided correlate to the researchers' perspectives and are based on educational research interests. Regarding the different ways' adolescents perceive their positions as learners, we find that both teachers (at school) and parents (at home) must unconditionally support students with low levels of motivation and self-perception. Therefore, adult attachment and 
involvement become more important to moderate those kinds of students in order to reconstruct their learning identities. This study ultimately confirms that there is a reciprocal relationship between learner identity and learner awareness and further will support the integrated effects on both learner autonomy and cognitive ability. The results also demonstrate that adult (in this case teachers and parents) involvement with adolescents' learning approaches may encourage the learners to become less or more autonomous people. Also, adolescents who already know their position as learners, tend to be responsible for their own learning, associating with self-directed learning, due to their autonomy as independent students.

The implications of this study focus on practice and research interests. For students, this study is expected to increase the level of their personal values, from less-consciousness to more-consciousness of learning identity through their involvement in this research. Furthermore, for teachers, this research enables teachers or parents to investigate their roles in adolescents' identity formation process. Also, by understanding of the outcomes of this study, we expect teachers can easily identify the correlation between learner identity and level of learner awareness in the context of adolescents' identity formation. This study also will give new references in similar research contexts for professional groups and worldwide educational systems. Basically, teachers may act as sanctioners for their students (Hamman and Hendricks, 2005), such as to help them in figuring out their academic identities, to find ways to value students' achievements, and to create comforFigure environments for either identity formation or development by providing effective instructions and guiding adolescents' perspectives in order to prepare their future as they want.

This study was financially supported by Sukma Foundation. The School of Education, University of Tampere is also gratefully acknowledged. 


\section{BIBLIOGRAPHY}

Adamson, L., S.G. Hartman and B. Lyxell. 1999. "Adolescent Identity: A Qualitative Approach: Self-concept, Existential Questions and Adult Contacts." Scandinavian Journal of Psychology 40: 21-31.

American Psychologist Association. 2002. "Developing adolescents: A reference for professionals."

Andrade, $\mathrm{H}$ and Y. Du. 2007. "Students responses to criteriareferenced self-assessment." Assessment and Evaluation in Higher Education 32(2): 159-181.

Bandura, A. 1977. "Self-efficacy: Toward a unifying theory of behavioral change." Psychological Review, 84 (2): 191-215.

Bandura, A. and N. E. Adams. 1977. "Analysis of self-efficacy theory of behavioral change." Cognitive Therapy and Research 1 (4): 287-310.

Bartholomew, K. 1990. "Avoidance of intimacy: An attachment perspective." Journal of Social and Personal Relationships 7 (2): 147-178.

Bartholomew, K. and L. M. Horowitz. 1991. "Attachment styles among young adults: A test of a four-category model." Journal of Personality and Social Psychology 61 (2): 226.

Bong, M. and E. M. Skaalvik. 2003. "Academic self-concept and self-efficacy: How different are they really?" Educational Psychology Review 15 (1): 1-40.

Bosnjak, L. and C. Winkelman. 2003. "The contribution of attachment style to identity formation in late adolescence." In Relationships: Family; Work and Community, edited by K.A. Moore. Proceedings of the 3rd Australasian Psychology of Relationships Conference. Melbourne, Australia: Australian Psychological Society.

Choy, S. C., P. S. C. Goh and D. S. Sedhu. 2016. "How and why students learn: Development and validation of the learner awareness levels questionnaire for higher education students." International Journal of Teaching and Learning in Higher 
Education 28 (1): 94-101.

Choy, S. C., P. S. C. Goh and Y. L. Liew. 2015. "Learner awareness levels questionnaire: Development and preliminary validation of the English and Malay versions to measure how and why students learn." World Academy of Science, Engineering and Technology, International Journal of Social, Behavioral, Educational, Economic, Business and Industrial Engineering 9 (10): 3180-3184.

Coll, C. and L. Falsafi. 2010. "Learner identity. An educational and analytical tool La identidad de aprendiz." Una herramienta educativa y analítica. Identidad y Educación 353: 211-233.

Falsafi, L. 2010. "Learner identity: A sociocultural approach to how people recognize and construct themselves as learners." Doctorado interuniversitario de psicologia de la educacion. Doctoral thesis. Universidad de Barcelona.

Hamman, D. and C. B. Hendricks. 2005. The role of the generations in identity formation: Erikson speaks to teachers of adolescents. The Clearing House: A Journal of Educational Strategies, Issues and Ideas 79 (2): 72-75.

Harré, R., F. M. Moghaddam, T. P. Cairnie, D. Rothbart and S. R. Sabat. 2009. "Recent advances in positioning theory." Theory and Psychology 19 (1): 5-31.

Harrison, R. 1978. "How to design and conduct self-directed learning experiences2. Group and Organization Management 3 (2): 149-167.

van Langenhove, L. and R. Harré. 1999. "Introducing positioning theory." In Positioning theory: Moral contexts of intentional action, edited by R. Harré, L. van Langenhove and L. Bermann. British Library, UK: Blackwell Publisher Ltd.

Larsson. J. and I. Holmstrom. 2007. "Phenomenographic or phenomenological analysis: Does it matter? Examples from a study on anesthesiologists' work." International Journal of Qualitative Studies on Health and Well-being 2: 55-64.

Lewis, T. 2006. "When teaching is learning: A personal account of 
learning to teach online." Calico Journal, 581-600.

Matthews, J. S., M. Banerjee and F. Lauermann. 2014. "Academic identity formation and motivation among ethnic minority adolescents: The role of the "self" between internal and external perceptions of identity." Child Development 85 (6): 2355-2373.

Nurhayati and RS Dewi. 2017. "An Analysis of Adolescents' Identity Positioning as Learners in Sukma Bangsa Pidie. School." Master Thesis in University of Tampere.

Nurhayati, RS Dewi, P Räihä and E Ropo. 2018. "Reconstructing Learners' Identity through Learning Awareness of Adolescents in Sukma Bangsa Pidie (SBP) School." Technology-Enhanced Assessment Conference.

Nurhayati, RS Dewi, P. Räihä and E. Ropo. 2017. "Adolescents' Identity Formation as Learners in Sukma Bangsa School Pidie, Aceh, Indonesia." Sukma: Jurnal Pendidikan 1 (2): 249-280.

Reeve, J. and H. Jang. 2006. "What teachers say and do to support students' autonomy during a learning activity." Journal of Educational Psychology 98 (1): 209.

Reeve, J. and H. Jang. 2006. "What teachers say and do to support students' autonomy during a learning activity." Journal of Educational Psychology 98 (1): 209.

Riley, P. 2011. Attachment theory and the teacher-student relationship: A practical guide for teachers, teacher educators and school leaders. Routledge.

RS Dewi, Nurhayati, P. Räihä, E. Ropo. 2018. “What leads adolescent confused with their learning identity in Sukma Bangsa Pidie (SBP) School." Technology-Enhanced Assessment Conference.

Schunk, D. H. 1991. "Self-efficacy and academic motivation." Educational Psychologist 26 (3-4): 207-231.

Song, L. and J. R. Hill. 2007. "A conceptual model for understanding self-directed learning in online environments." Journal of Interactive Online Learning 6 (1): 27-42.

Tirado, F., and A. Gálvez. 2008. "Positioning theory and discourse 
analysis: Some tools for social interaction analysis." Historical Social Research/Historische Sozialforschung, 224-251.

Vagan, A. 2011. "Towards a sociocultural perspective on identity formation in education." Mind, Culture, and Activity 18 (1): 43-57. 